\title{
Empirical Linkage of Intellectual Capital and Performance of Islamic Banks
}

\author{
Sarah Athirah Saruchi, Nor Aiza Mohd Zamil, Rohaida Basiruddin, Siti Zaleha Abdul Rasid, \\ Nor Faezah Ghazi Ahmad
}

\begin{abstract}
With the eminence of the era of knowledge-based economies, the concept of intellectual capital (IC) is of vital importance for organisations to survive in these vigorous environments. As one of the knowledge intensive sectors, there is no exception to banking institutions in enhancing their intellectual capital efficiency to the forefront especially for Islamic banks (IBs) that have to compete with the firmlyestablished conventional banks. Accordingly, this study intends to measure the relationship between intellectual capital efficiency and banks' performance. In total, 59 Islamic banks are selected and their audited annual reports are compiled from the banks' websites respectively from year 2006-2017. Value-added intellectual coefficient (VAIC) are applied in measuring IC efficiency. The findings provide empirical evidences of positive relationship between IC efficiency and banks performance, nonetheless, when decomposes into human capital efficiency (HCE), structural capital efficiency (SCE) and capital employed efficiency (CEE), only human capital efficiency shows significant positive relationship with performance of the banks while the other two components show significant negative linkage with bank performance. Furthermore, due to criticisms towards VAIC method, this study using modified value-added intellectual capital coefficient (MVAIC) and found that MVAIC has significant positive relationship with bank performance while relational capital as additional variable in MVAIC regression model has no significant effect with bank performance. This study provides better insights on the importance of utilisation of IC by banking institutions particularly for Islamic banks.
\end{abstract}

Index Terms: bank's performance, intellectual capital; banks' MVAIC, VAIC

\section{INTRODUCTION}

The evolving contour of knowledge-based economies has caused many organisations to stop depending solely on physical assets in order to elevate their productions or performances. In fact, they started to realize that there is actually an unseeable driver that leads to better organisational performance, which is intangible asset that famously known as intellectual capital (IC). Roos (1) elucidated, as a way to identify and visualise the hidden value creation within organisation, the concept of IC has been introduced in which closely related to the empowerment of knowledge in an organisation. To add on, with the onset of knowledge-based economies from

Revised Manuscript Received on April 19, 2019.

Sarah Athirah Saruchi, Azman hashim International Business School, Universiti Teknologi Malaysia, Kuala Lumpur, Malaysia.

Nor Aiza Mohd Zamil, Azman hashim International Business School, Universiti Teknologi Malaysia, Kuala Lumpur, Malaysia.

Rohaida Basiruddin, azman hashim international business school, universiti teknologi malaysia, kuala lumpur, malaysia

Siti Zaleha Abdul Rasid, Azman hashim International Business School, Universiti Teknologi Malaysia, Kuala Lumpur, Malaysia

Nor Faezah Ghazi Ahmad, Azman hashim International Business School, Universiti Teknologi Malaysia, Kuala Lumpur, Malaysia industrial economies, the players found that the prevailing drivers of economy neither the financial assets like capital nor physical assets like land or equipment yet the people and their knowledge (2). It is because as highlighted by Kesse and Pattanayak (3), "knowledge has become the new engine driving organisations' wealth". Further, it is important to be cognisant of the importance of knowledge creation or in part, the significance of IC on financial performance (4) which can directly sustain the competitive advantage $(5,6)$ of particular organisation. Simply put, IC can be defined as the intangible assets that comprise of knowledge, experience, customer rapport and infrastructure that elevate the performance of organisation due to its ability to create value creation and competitive advantage.

Accordingly, intellectual capital has also become a prominent subject to delve into with respect to the banking field as one of the knowledge intensive sectors (7) because it relies upon a massive amount of human capital and customer relations (8) for its survival. Hence the banking field has to stay innovative and aggressive in developing new products and services (9) especially in the current rapidly changing global environment. Incessant innovation and knowledge creation have become the key sources for sustainable competitive advantage (10) since at its heart, the whole operations of banks build upon ingenuity, accommodating unique services and offering great products (3).

Realising the importance of IC to organisational performance, there are numbers of studies that build distinctive methods in measuring IC (11). Nonetheless, the most widely-applied method in gauging IC is Value-Added Intellectual Coefficients (VAIC) that has been developed by Pulic (12). The method has garnered increasing attention from researchers in identifying the relationship between IC efficiency and organisational performance $(4,13,14)$. It also has been used in numerous studies in banking sector especially in analysing the linkage between IC efficiency and banks' performance across many countries like Turkey (11), India (15, 16), Thailand (17), Ghana (13), Malaysia (18) and so forth. However, drawing upon the past literature, there are dearth of empirical studies that already performed specifically for Islamic banks even though as explicated by Nawaz and Haniffa (19) due to Islamic banking nature, the banks need to develop innovative products differ from the conventional banks because they have to perform business according to Shariah principles (20). Corresponding to that, they have to empower their intangible assets like human 
capital to stay competitive in the market. Thence, this study seeks to measure the impact of IC efficiency on Islamic banks' performance. Due to criticisms towards VAIC method since there is exclusion of one of the main components of IC namely relational capital in the computation, so that, this study also intends to measure IC efficiency against banks' performance using Modified Value Added Intellectual Capital (MVAIC).

The study is organised as follows; the second section deliberates the intellectual concept in regard of definitions, components and VAIC method as well as reviews the preceding literatures that examining IC efficiency using VAIC specifically in banking sector. The subsequent section demonstrates the data, regression models and hypotheses pertinent to this study. The next section presents and discusses the empirical regression results and the final part includes the summary of the results in this study.

\section{LITERATURE REVIEW}

\section{A. Intellectual Capital}

The bulk of past researches oftentimes give the definition of intellectual capital in which lead to incongruity of the definition by academic scholars. As one of pioneers who spearheaded the intellectual capital studies, Edvinsson and Stenfelt (21) defined intellectual capital as "intellectual capital assets; i.e. the knowledge, experience and technical infrastructure, customer relations, routines and professional competencies that create the future earnings potential'. In recent discourse of intellectual capital, Meles, Porzio (22) defined intellectual capital as the intangible asset that constituted of knowledge and know-how that confer the competitive advantage over other competitors as well as portray the organisation itself. Congeneric to the diverse definitions of VAIC, there are no uniform opinions on the components of intellectual capital. The classification differs according to understanding and points of view on IC by the academic scholars but most of millennia researches classified IC into three components namely human capital, structural capital and relational capital. Human capital involves the skills, know-how, experiences that they have as well as their abilities (23). Structural capital involves the corporate culture, technology systems, intellectual property such as patents, trademarks, and copyrights, the management processes as well as the learning capacity that can create value for the organisation (13). On the other hand, relational capital can be defined as the build of relationships that any organisation has with the external world, where the external world consists of customers, shareholders and any other agents that may influence the organisation's well-being (22). managerial, cultural and organisational changes is customarily suggests to the organisation on how to plan and manage its intellectual capital efficiently in order to create value. There are numbers of measurement methods that have been employed by researchers as a way to measure the efficacy of intellectual capital of particular organisation. Despite having a variety of IC measurement methods, afore cited, VAIC is the most applied method in determining the
Measuring intellectual capital which encompassing the

IC value. This is because the advantages that has been offered by VAIC such as it provides straightforward computation and uncomplicated procedure in measuring the value creation (24), it can be applied regardless the size of organisation (25) and it is very easy to use (26). As pinpointed by Adesina (27), this applicable method measures IC through the value creation efficiency in particular organisation as well as demonstrates the intellectual ability of organisation whether its sources have been utilised efficiently or vice versa (3).

\section{B. Application of VAIC Method in Banking Sector}

A significant volume of research on the theme of intellectual capital has emerged drastically where there is no exception to banking sector. All the studies reviewed hitherto, it can conclude that IC studies are important to be conducted especially most of studies found positive linkage between IC efficiency as proxies by VAIC and bank performance $(11,16,22,28)$. In recent discourse of intellectual capital and bank performance, the similar pattern can be seen which is the studies mostly did not measure VAIC value standalone but they segregate into its components to attain more far-reaching findings. For instance, Tiwari and Vidyarthi (29) found that there are positive linkage between VAIC and performance of public and private banks that operating in India but only human capital and structural capital posit positive relationship with performance. The dissenting findings as found by Ozkan, Cakan (11) demonstrated significant positive relationship between VAIC, HCE and CEE on performance. This is in concert with study conducted by Mohammed and Irbo (30) who found that $\mathrm{HCE}$ and $\mathrm{CEE}$ have significant relationship on bank performance while SCE has no significant relationship with bank performance. Notwithstanding, with diverse findings on VAIC and bank performance, Tran and Vo (17) conducted such study on listed banks in Thailand and found that VAIC has no significant relationship with financial performance of the banks but based on individual components of IC, CEE is the most important components that contribute to bank performance. Meanwhile Poh, Kilicman (18) have conducted a study on ten local banks in Malaysia and the study found that VAIC and all its three components have significant relationship with bank performance indicators. Focusing on Islamic banks, Nawaz and Haniffa (19) found that there are positive associations between VAIC and its individual components which are $\mathrm{CEE}$ and $\mathrm{HCE}$ and financial performance of 64 Islamic banks while SCE has no significant relationship with performance. Since VAIC method has been criticised by numbers of economic scholars due to exclusion of few items, therefore, this study uses MVAIC method which involves relational capital as done by Vidyarthi (16) and Tiwari and Vidyarthi (29) where the former found that MVAIC has significant positive relationship with bank efficiency while the latter discovered that there is not much difference between VAIC and MVAIC. 
Based on previous studies as shown above, there are mixed empirical evidences on the relationship between IC efficiency and bank performance, besides, there are paucity of studies that examine the linkage between IC efficiency and performance of Islamic banks. Therefore, these reasons have gravitate this study to determine the relationship between IC efficiency and performance of Islamic banks with additional method namely modified value added intellectual coefficient as has been explained previously.

\section{METHODOLOGY}

\section{A. Data}

The pertinent data are extracted from the Bankscope database and the banks' annual reports that are publicly available in their websites respectively. In the first stage of sample selection, there are 163 Islamic banks across 34 countries. However, due to data availability, the final sample consists of a panel of 59 Islamic banks involving 19 countries, over the twelve-year period of 2006 to 2017. The samples encompassing the banks from Southeast Asia countries namely Brunei, Indonesia, Malaysia and Thailand, South Asia countries which are Bangladesh and Pakistan, Middle East countries namely Bahrain, Egypt, Jordan, Kuwait, Lebanon, Palestine, Qatar, Saudi Arabia, Tunisia, Turkey and United Arab Emirates, Southern Africa country which is South Africa and lastly Northern Europe country namely United Kingdom. The country-wise sample distribution for this study is as presented in Table 1 where United Arab Emirates represents $13.56 \%$ of the overall samples, which is the highest, whilst Brunei, Thailand, Palestine, Lebanon, Tunisia and South Africa notably represent only $1.69 \%$ of the total samples each.

Table 1: Distribution of Sample Banks

\begin{tabular}{|l|c|c|}
\hline \multicolumn{1}{|c|}{ Country } & Islamic banks & Percentage (\%) \\
\hline Bahrain & 5 & 8.48 \\
\hline Bangladesh & 5 & 8.48 \\
\hline Brunei & 1 & 1.69 \\
\hline Egypt & 2 & 3.39 \\
\hline Indonesia & 4 & 6.78 \\
\hline Jordan & 2 & 3.39 \\
\hline Kuwait & 4 & 6.78 \\
\hline Lebanon & 1 & 1.69 \\
\hline Malaysia & 7 & 11.86 \\
\hline Pakistan & 5 & 8.48 \\
\hline Palestine & 1 & 1.69 \\
\hline Qatar & 4 & 6.78 \\
\hline $\begin{array}{l}\text { Saudi } \\
\text { Arabia }\end{array}$ & 3 & 5.09 \\
\hline South Africa & 1 & 1.69 \\
\hline Thailand & 1 & 1.69 \\
\hline Tunisia & 1 & 1.69 \\
\hline Turkey & 2 & 3.39 \\
\hline $\begin{array}{l}\text { United Arab } \\
\text { Emirates }\end{array}$ & 8 & 13.56 \\
\hline $\begin{array}{l}\text { United } \\
\text { Kingdom }\end{array}$ & & $\mathbf{1 0 0}$ \\
\hline Total & $\mathbf{5 9}$ & 3.39 \\
\hline
\end{tabular}

\section{B. Dependent Variables}

The performance of Islamic banks in this study is measured based on return on assets (ROA) of the banks and is calculated by dividing the net income of the year by total assets. This measure has been used in many empirical studies $(11,19,29,31)$ as an indicator of banks' performance. Hajer and Anis (32) then define the ROA variable as the ability of the bank to generate a certain level of operational benefits or in other words, the capability of bank to create profits from their assets (33).

\section{Independent Variables}

Intellectual capital efficiency is the dependent variable in this study. As proposed by Pulic (12), the value added approach which famously known as VAIC is regarded as the apropos measure to calculate and oversee the efficiency of value creation of particular organisation. He further explained that the higher the utilisation of intellectual capital, the higher the value creation efficiency of that organisation will be. At current, due to its advantages which are publicly available that makes the data is easy to obtain and is quantitative in nature, whereby the data can be calculated facilely (Chan, 2009), so that, many empirical studies applied VAIC to measure IC efficiency $(11,16,19$, 34) Specifically, VAIC methodology has been widely used in studies that analysing the impact of IC efficiency on corporate performance. To add up, it illustrates the information on the efficiency of both tangible and intangible assets that are able to elevate the performance (29). It is a consistent approach which composed of three components namely Human Capital Efficiency (HCE), Structural Capital Efficiency (SCE) and Capital Employed Efficiency (CEE). In essence, the convenient process and widely applicable of VAIC has gravitates this study to measure intellectual capital efficiency of the banks using this method. Nonetheless, due to criticisms on this method, since one of the main compositions of intellectual capital namely relational capital is not included in the calculation, this study will include relational capital component using Modified Value-Added Intellectual Coefficient (MVAIC) that already applied very recently by Vidyarthi (16) and Tiwari and Vidyarthi (29) in order to attain more robust results. The items needed to compute VAIC and MVAIC can be collected on balance sheets and income statements. VAIC is the sum of HCE, SCE and CEE while MVAIC is the sum of HCE, SCE, CEE and relational capital efficiency (RCE). The formulae as follows:

$$
\begin{gathered}
V A I C_{i}=H C E_{i}+S C E_{i}+C E E_{i} \\
M V A I C_{i}=H C E_{i}+S C E_{i}+C E E_{i}+R C E_{i}
\end{gathered}
$$

Where VA can be measured by summing profit before tax and payroll expenses as computed by Tran and Vo (17). HC refers to payroll expenses, while in attaining the value of $\mathrm{SC}, \mathrm{HC}$ value is deducted from the value of VA. CE is measured by subtracting total assets from intangible assets, whereas RC is the sum of advertising and marketing expenditure. 
International Conference on Recents Advancements in Engineering and Technology (ICRAET-18) |15th and 16th March 2019|Siddhartha Institute of Technology \& Sciences, Telangana, India.

\section{Control Variables}

In line with previous studies, bank-specific variables namely bank size which proxied by natural logarithm of total bank's assets $(3,17,29)$ and bank's age which proxied by number of years since banks' incorporation are being used as the control variable. In addition, due to main reason in choosing the sample period which is from 2006-2017, the study included the impact of financial crisis dummy variable taking the value of 1 for 2008-2009 and 0 otherwise $(3,35)$. The summary of all variables that have been computed in this study are presented in Table 2 .

Table 2: Summary of Variables

\begin{tabular}{|c|c|c|c|}
\hline Type of Variable & Variable & $\begin{array}{l}\text { Abbreviation of } \\
\text { variable }\end{array}$ & Measurement \\
\hline Dependent & Return on Asset & ROA & Net income/ Total assets \\
\hline \multirow[t]{6}{*}{ Independent } & $\begin{array}{l}\text { Value Added Intellectual } \\
\text { Coefficient }\end{array}$ & VAIC & $\mathrm{VAIC}=\mathrm{HCE}+\mathrm{SCE}+\mathrm{CEE}$ \\
\hline & $\begin{array}{l}\text { Modified Value Added } \\
\text { Intellectual Coefficient }\end{array}$ & MVAIC & MVAIC = HCE+SCE+CEE+RCE \\
\hline & Human Capital Efficiency & HCE & $\mathrm{HCE}=\mathrm{VA} / \mathrm{HC}$ \\
\hline & $\begin{array}{ll}\text { Structural } & \text { Capital } \\
\text { Efficiency } & \end{array}$ & SCE & $\mathrm{SCE}=\mathrm{SC} / \mathrm{VA}$ \\
\hline & $\begin{array}{ll}\text { Capital } & \text { Employed } \\
\text { Efficiency } & \end{array}$ & CEE & $\mathrm{CEE}=\mathrm{VA} / \mathrm{CE}$ \\
\hline & $\begin{array}{ll}\text { Relational } & \text { Capital } \\
\text { Efficiency } & \\
\end{array}$ & RCE & $\mathrm{RCE}=\mathrm{RC} / \mathrm{VA}$ \\
\hline \multicolumn{4}{|l|}{ Control } \\
\hline \multirow[t]{2}{*}{ Bank-specific } & Bank Size & SIZE & Log of total assets \\
\hline & Bank Age & AGE & Number of years since banks' incorporation \\
\hline Macroeconomic & Crisis & Crisis & $\begin{array}{l}\text { Dummy variable with the value of } 1 \text { for the } \\
\text { year of } 2008 \text { and } 2009 \text {, and zero otherwise }\end{array}$ \\
\hline
\end{tabular}

E. Regression Models and Hypotheses of the Study

Table 3: Regression Models

\begin{tabular}{|l|c|}
\hline \multicolumn{1}{|c|}{ Model } & Functional Representations \\
\hline Model 1 & $R O A=\beta_{1}+\beta_{2}$ VAIC $+\beta_{3} S I Z E+\beta_{4} A G E+\beta_{5}$ Crisis $+\varepsilon$ \\
\hline Model 2 & $R O A=\beta_{1}+\beta_{2} M V A I C+\beta_{3} S I Z E+\beta_{4} A G E+\beta_{5}$ Crisis $+\varepsilon$ \\
\hline Model 1a & $R O A=\beta_{1}+\beta_{2} H C E+\beta_{3} S C E+\beta_{4} C E E+\beta_{5} S I Z E+\beta_{6} A G E+\beta_{7}$ Crisis $+\varepsilon$ \\
\hline Model 2a & $R O A=\beta_{1}+\beta_{2} H C E+\beta_{3} S C E+\beta_{4} C E E+\beta_{5} R C E+\beta_{6} S I Z E+\beta_{7} A G E+\beta_{8} C r i s i s+\varepsilon$ \\
\hline
\end{tabular}

In order to examine the relationship between intellectual H1: There is a significant positive relationship between

Notes: ROA is return on asset. VAIC, MVAIC, HCE, SCE, RCE, SIZE, AGE, Crisis are value-added intellectual coefficient, modified value-added intellectual coefficient, human capital efficiency, structural capital efficiency, capital employed efficiency, relational capital efficiency, natural logarithm of total assets, number of years since banks' incorporation and dummy variable with the value of 1 for the year of 2008 and 2009 and 0 for otherwise respectively.

capital and bank performance, four regression models have been formed as viewable in Table 2. Model 1 indicated the linkage between banks' performance and VAIC, while Model 1a decomposed the components of VAIC namely human capital efficiency, structural capital efficiency and capital employed efficiency in order to know their individual effects on banks' performance. Aforementioned, this study also test the effect of relational capital component to banks' performance. Hence, Model 2 is created to identify the association between MVAIC and banks' performance, while Model 2a consists of the three main components of VAIC method which are HCE, SCE and CEE with one other component which is relational capital efficiency (RCE) against ROA as the proxy of banks' performance.

The study seeks to identify the impact of VAIC, MVAIC and their components namely HCE, SCE, CEE and REE on Islamic banks' performance. Therefore, in order to attain the objective, the following hypotheses are being tested in this study. value added intellectual capital coefficient (VAIC) of Islamic

banks and their performance indicator (ROA).

H2: There is a significan positive relationship between modified value added intellectual capital coefficient (MVAIC) of Islamic banks and their performance

indicator (ROA).

H3: There is a significant positive relationship between human capital efficiency (HCE) of Islamic banks and their performance indicator (ROA).

H4: There is a significant positive relationship between 
structural capital efficiency (SCE) of Islamic banks and their performance indicator (ROA).

H5: There is a significant positive relationship between capital employed efficiency (CEE) of Islamic banks and their performance indicator (ROA).

H6: There is a significant positive relationship between relational capital efficiency (RCE) of Islamic banks and their performance indicator (ROA).

\section{FINDINGS}

\section{A. Descriptive Statistics}

Table 4 displays the descriptive statistics of IC variables as independent variables along with ROA as dependent variable and three control variables. Based on the table below, the mean value of VAIC is 3.633 while MVAIC is 3.986. If compared with studies that conducted in other individual countries, the mean value of VAIC_in_this study is higher than the mean value of VAIC of the banks that are operating in India (3.45) (29), banks in Thailand (0.683) (17) banks in Ghana (2.088) (13) and banks in Tanzania (2.738) and it is approximately equal to the mean value of VAIC of the banks that are operating in Indonesia (3.636) and Turkey (3.887) (11). However, it is lower than the banks that are operating in Qatar (8.191) (35). The negative signs of the values of IC variables demonstrate that the costs borne by the banks in investing IC more than what IC can assist in improving the banks' performance (3). Focusing on mean of ROA which recorded 1.425 shows that, in average, the sampled Islamic banks are able to generate profit from their assets during the study period.

Table 4: Descriptive Statistics of Variables

\begin{tabular}{|l|l|l|l|l|}
\hline $\begin{array}{l}\text { Variabl } \\
\text { es }\end{array}$ & Mean & Minimum & Maximum & $\begin{array}{l}\text { Standard } \\
\text { deviation }\end{array}$ \\
\hline VAIC & 3.633 & -2.910 & 15.344 & 2.262 \\
\hline MVAIC & 3.986 & -2.664 & 15.633 & 2.660 \\
\hline HCE & 2.768 & -4.136 & 14.225 & 2.094 \\
\hline SCE & 0.618 & -2.840 & 9.167 & 0.720 \\
\hline CEE & 0.247 & -1.169 & 12.218 & 0.870 \\
\hline RCE & 0.198 & -0.866 & 12.646 & 1.294 \\
\hline SIZE & 14.839 & 8.888 & 18.332 & 1.656 \\
\hline AGE & 17.906 & 0.000 & 60.000 & 13.358 \\
\hline Crisis & 0.167 & 0.000 & 1.000 & 0.373 \\
\hline ROA & 1.425 & -4.920 & 13.080 & 1.987 \\
\hline
\end{tabular}

Source: Author's calculation

Table 5 presents the mean annual values of intellectual capital variables of 59 Islamic banks from 2006 to 2017. Based on Table 4, it can be concluded that human capital efficiency is the most important component in explaining VAIC with the average value of $\mathrm{HCE}$ is 2.768 . It is consonant with many prior researches $(11,16,19)$. In comparison with past studies in respect of mean annual value of VAIC within the same period of time, the average value of VAIC in this study (3.633) is slightly higher than the value recorded by the banks that are operating in India (3.010) studied by Kesse and Pattanayak (3). Meanwhile, in comparison with studies in regard of Islamic banks as the study sample, the mean annual value is slightly lower that the value recorded by Islamic banks that are operating in 21 countries (3.93) studied by Nawaz and Haniffa (19).

Table 5: Mean Annual Values of IC Variables

\begin{tabular}{|c|c|c|c|c|c|c|}
\hline Year & $\begin{array}{l}\text { VAI } \\
\text { C }\end{array}$ & $\begin{array}{l}\text { MVAI } \\
\text { C }\end{array}$ & $\begin{array}{l}\text { HC } \\
\mathbf{E}\end{array}$ & SCE & CEE & $\begin{array}{l}\mathbf{R C} \\
\mathbf{E}\end{array}$ \\
\hline 2006 & 5.208 & 5.561 & $\begin{array}{l}3.78 \\
7\end{array}$ & $\begin{array}{l}0.54 \\
4\end{array}$ & 0.877 & $\begin{array}{l}0.11 \\
0\end{array}$ \\
\hline 2007 & 4.618 & 4.539 & $\begin{array}{l}3.40 \\
5 \\
\end{array}$ & $\begin{array}{l}0.80 \\
0\end{array}$ & 0.412 & $\begin{array}{l}0.04 \\
3\end{array}$ \\
\hline 2008 & 4.704 & 5.336 & $\begin{array}{l}3.54 \\
4 \\
\end{array}$ & $\begin{array}{l}0.86 \\
5 \\
\end{array}$ & 0.296 & $\begin{array}{l}0.05 \\
2\end{array}$ \\
\hline 2009 & 3.277 & 4.162 & $\begin{array}{l}2.56 \\
0 \\
\end{array}$ & $\begin{array}{l}0.54 \\
9\end{array}$ & 0.168 & $\begin{array}{l}0.03 \\
3\end{array}$ \\
\hline 2010 & 3.384 & 4.086 & $\begin{array}{l}2.47 \\
7 \\
\end{array}$ & $\begin{array}{l}0.66 \\
1 \\
\end{array}$ & 0.246 & $\begin{array}{l}0.30 \\
5 \\
\end{array}$ \\
\hline 2011 & 3.306 & 3.664 & $\begin{array}{l}2.49 \\
3 \\
\end{array}$ & $\begin{array}{l}0.60 \\
9 \\
\end{array}$ & 0.204 & $\begin{array}{l}0.03 \\
3 \\
\end{array}$ \\
\hline 2012 & 3.693 & 4.042 & $\begin{array}{l}2.80 \\
9 \\
\end{array}$ & $\begin{array}{l}0.70 \\
6 \\
\end{array}$ & 0.178 & $\begin{array}{l}0.19 \\
7\end{array}$ \\
\hline 2013 & 3.481 & 3.755 & $\begin{array}{l}2.70 \\
8 \\
\end{array}$ & $\begin{array}{l}0.68 \\
4 \\
\end{array}$ & 0.091 & $\begin{array}{l}0.26 \\
8 \\
\end{array}$ \\
\hline 2014 & 3.480 & 3.556 & $\begin{array}{l}2.69 \\
9 \\
\end{array}$ & $\begin{array}{l}0.50 \\
5 \\
\end{array}$ & 0.276 & $\begin{array}{l}0.05 \\
2 \\
\end{array}$ \\
\hline 2015 & 3.403 & 3.749 & $\begin{array}{l}2.64 \\
3 \\
\end{array}$ & $\begin{array}{l}0.54 \\
4 \\
\end{array}$ & 0.215 & $\begin{array}{l}0.31 \\
6 \\
\end{array}$ \\
\hline 2016 & 3.646 & 4.106 & $\begin{array}{l}2.84 \\
3 \\
\end{array}$ & $\begin{array}{l}0.54 \\
7 \\
\end{array}$ & 0.255 & $\begin{array}{l}0.32 \\
0\end{array}$ \\
\hline 2017 & 3.357 & 3.671 & $\begin{array}{l}2.54 \\
0 \\
\end{array}$ & $\begin{array}{l}0.56 \\
5 \\
\end{array}$ & 0.250 & $\begin{array}{l}0.32 \\
5 \\
\end{array}$ \\
\hline $\begin{array}{l}\text { Avera } \\
\text { ge }\end{array}$ & 3.633 & 3.986 & $\begin{array}{l}2.76 \\
8 \\
\end{array}$ & $\begin{array}{l}0.61 \\
8 \\
\end{array}$ & 0.247 & $\begin{array}{l}0.19 \\
8 \\
\end{array}$ \\
\hline
\end{tabular}

Source: Author's calculation

\section{B. Diagnostic Checks}

Pearson correlation analysis is being conducted to check whether there is multicollinearity that exists in the regression model or not or is there any strong correlation between these independent variables. Based on the results as shown in Table 6, there is no strong correlation between intellectual capital variables as the proxies of independent variables, except for VAIC and HCE, along with VAIC and MVAIC correlations which notably recorded 0.909 and 0.869 respectively, notwithstanding as justified by Kesse and Pattanayak (3), there is no issue arose since these variables are regressed in the different equations. On the other side, focusing on the relationship between IC variables and dependent variable which is ROA, it is worth noting that HCE has the highest correlation with ROA (0.389) while SCE has the lowest correlation with ROA (0.014).

Subsequent to multicollinearity test, with respect to panel data analysis, Breusch and Pagan Langrangian Multiplier test (36) has been done to test whether pooled OLS is adequate as compared to random effect estimation.

The result shows that the variance of the individualspecific effects is not equal to zero, therefore, pooled OLS estimation is rejected. In brief, it is not advisable to use pooled OLS estimation since it will provide less valid 
International Conference on Recents Advancements in Engineering and Technology (ICRAET-18) |15th and 16th March 2019|Siddhartha Institute of Technology \& Sciences, Telangana, India.

inference. To decide whether to estimate using fixed-effects estimator or random-effects estimator, Hausman test (37) has been done where the study found that the former is the best estimator to produce more robust and valid results. It is because as explained by Frondel and Vance (38) the latter is preferable if and only if the correlation between individualspecific effects and $\mathrm{X}$ or variables in the regression model is zero. However, after running Hausman test, the assumption is unmet. Besides, of crucial importance in examining the existence of heteroskedasticty and autocorrelation issues in the models. After applying Modified Wald test for heteroskedasticity and Woolridge test for serial correlation, the study found that the regression models suffer both heteroskedasticity and autocorrelation. Therefore, in order to attain valid inference, the study apply remedial measure namely robust standard errors, and one of the perks of this measure is the robust heteroskedasticity-consistent standard errors are produced,

\section{C.Regression Results}

Table 7 presents the regression results concerning of Model 1, 1a, 2 and 2a which demonstrate the relationship between IC variables and performance of selected Islamic banks within the period of 2006-2017. Regression result of Model 1 shows that there is a positive and statistically significant relationship between VAIC and ROA as the proxy of bank performance which supports the hypothesis aforementioned that the banks with higher value of IC, have better performance. This is in concert with the findings of

Table 6: Correlation Matrix

\begin{tabular}{|c|c|c|c|c|c|c|c|c|c|c|}
\hline & VAIC & MVAIC & HCE & SCE & CEE & RCE & SIZE & AGE & Crisis & ROA \\
\hline VAIC & 1.000 & & & & & & & & & \\
\hline MVAIC & 0.869 & 1.000 & & & & & & & & \\
\hline HCE & 0.909 & 0.788 & 1.000 & & & & & & & \\
\hline SCE & 0.276 & 0.220 & 0.187 & 1.000 & & & & & & \\
\hline CCE & 0.240 & 0.222 & 0.116 & 0.331 & 1.000 & & & & & \\
\hline RCE & 0.049 & 0.452 & 0.047 & 0.052 & 0.015 & 1.000 & & & & \\
\hline SIZE & 0.232 & 0.224 & 0.313 & 0.179 & 0.228 & 0.034 & 1.000 & & & \\
\hline AGE & 0.065 & 0.056 & 0.027 & 0.060 & 0.129 & 0.003 & 0.219 & 1.000 & & \\
\hline Crisis & 0.123 & 0.088 & 0.125 & 0.053 & 0.009 & 0.044 & 0.123 & 0.107 & 1.000 & \\
\hline ROA & 0.308 & 0.264 & 0.389 & 0.014 & 0.118 & 0.023 & 0.105 & 0.042 & 0.037 & 1.000 \\
\hline
\end{tabular}

Nawaz and Haniffa (19), Poh, Kilicman (18) and Mondal and Ghosh (39). Meanwhile, the crisis as the control variable found to have a statistically significant negative relationship with ROA and this result is supported with the finding by Kesse and Pattanayak (3). The result is directly implies the negative impact of crisis to the performance of Islamic banks. Model 2 is an alternative model to Model 1 in respect of relationship of IC efficiency and banks' performance. The regression result of Model 2 demonstrates that MVAIC has a statistically significant positive relationship with bank performance as well. This result is agreeing the findings from prior studies by Tiwari and Vidyarthi (29) and Vidyarthi (16).

Model 1a shows the results when VAIC is split into its three components namely HCE, SCE and CEE to further investigate the impact of individual components to banks' performance.

Table 7: Regression Results

\begin{tabular}{|l|l|l|}
\hline $\begin{array}{l}\text { Independent } \\
\text { variables }\end{array}$ & Model 1 & Model 1a \\
\hline C & $7.368(5.914)$ & $12.629 * * *(4.832)$ \\
\hline VAIC & $0.377 * * *(0.102)$ & \\
\hline HCE & & \\
\hline SCE & & $0.604 * * *(0.148)$ \\
\hline CEE & & $-0.189 * * *(0.084)$ \\
\hline SIZE & $-0.447(0.450)$ & $-0.295 * * *(0.109)$ \\
\hline AGE & $-0.032(0.053)$ & $0.013(0.051)$ \\
\hline Crisis & $-0.408^{* * *}(0.178)$ & $-0.468^{* * *}(0.182)$ \\
\hline
\end{tabular}

\begin{tabular}{|l|l|l|}
\hline Adjusted R $\mathbf{R}^{2}$ & 0.201 & 0.324 \\
\hline $\begin{array}{l}\text { Independent } \\
\text { variables }\end{array}$ & Model 2 & Model 2a \\
\hline C & $7.389(6.949)$ & $13.632^{* * *(5.987)}$ \\
\hline MVAIC & $0.318^{* * *(0.119)}$ & \\
\hline HCE & & $0.496^{* * *(0.154)}$ \\
\hline SCE & & $-0.118^{* *(0.132)}$ \\
\hline CEE & & $-0.380^{* *(0.131)}$ \\
\hline RCE & & $0.091(0.082)$ \\
\hline SIZE & $-0.426(0.549)$ & $-0.921 *(0.479)$ \\
\hline AGE & $-0.049(0.084)$ & $0.013(0.085)$ \\
\hline Crisis & $-0.372(0.272)$ & $-0.449 *(0.263)$ \\
\hline Adjusted $\mathbf{R}^{2}$ & 0.172 & 0.259 \\
\hline
\end{tabular}

Note: The numbers in the parentheses are the robust standard errors because the models suffer heteroskedasticity and autocorrelation. Hausman tests are being applied in determining the best estimator for regression models. All models using one way individual-specific fixed-effect. $* * *$ and $* *$ represent statistical significance at $1 \%$ and $5 \%$ respectively.

Findings imply that there is a positive relationship between HCE and ROA but SCE and CEE has negative association with banks' performance. Simply put, an increase in SCE and CEE diminish the performance of banks. The results are contrary with other studies like Ozkan, Cakan (11) and Alhassan and Asare (13) who 
proved the positive linkage between $\mathrm{CEE}$ and bank performance. The negative relationship between SCE and CEE and banks' performance seems to imply that the Islamic banks did not utilise these two components efficiently. The result also suggest the Islamic banks have utilised their human capital resources efficiently and of three components, the performance of the banks is primarily driven by HCE. Meanwhile banks' size and crisis as control variables have statistically significant negative relationship with banks' performance. Since there is an application of which included four components of VAIC which are HCE, SCE, CEE and one additional component namely RCE. The results produces quite similar findings with Model 1a which implied the positive relationship between HCE and performance while the other two components in contrast with the impact of HCE on performance. This model also proves that the performance of Islamic banks are not driven by RCE. In concert with regression results of Model 1a, where the results show that the banks' size and crisis have negative relationship with performance. The negative relationship between banks' size and performance indicates that the smaller the banks' size, the higher the performance. Furthermore, in terms of the explanatory powers of the models in this study, the values of adjusted $\mathrm{R}^{2}$ when decomposing the VAIC into three and four components are notably recorded as 0.324 and 0.259 respectively, which is higher that the values of $\mathrm{R}^{2}$ in Model 1 and 2. This implies that the components of VAIC which are HCE, SCE, CEE and RCE are able to explain ROA better than VAIC and MVAIC alone. This result is similar with the inference by Ozkan, Cakan (11).

\section{CONCLUSION}

The results provided might prove beneficial specifically for Islamic banks in order to keep enhance the utilisation of IC because as reported, VAIC and MVAIC show positive relationship to the bank performance. In essence, this estimates provides a nuanced view on how to utilise IC resources efficiently in order to elevate the bank performance. Besides, based on regression results of individual components of IC, only human capital efficiency has significant positive relationship with bank performance while structural capital efficiency and capital employed efficiency show significant negative relationship. Meanwhile, relational capital efficiency has no significant relationship with bank performance. The results suggest manager of Islamic banks should utilise their human capital resources vigorously for instance via trainings in order to boost the profitability and performance of the banks.

The limitation of this study is the small sample size due to data availability and applying only one dependent variable (ROA) as the proxy of bank performance. To augment the development of IC in banking sector, more researches have to be conducted especially for Islamic banks. The continuous endeavours have to put forth since Islamic banks are expected to possess more knowledgeable employees and higher technology systems. It is because they have to produce more complicated products which is to be aligned with Shariah law as well as they have to compete against the long-established conventional banks. So, the future research MVAIC method, Model 2a shows the regression results

can extend the study with larger sample of Islamic banks or classify the Islamic banks based on bank types either it is domestic or foreign bank in order to get more valuable findings.

\section{REFERENCES}

1. Roos J. Exploring the concept of intellectual capital (IC). Long Range Planning. 1998;31(1):150-3.

2. Rahimi G, Seyyedi MH, Damirchi Q, editors. The role of tacit knowledge in innovation of public management. 2012 International Conference on Education and Management Innovation [IPEDR]; 2012.

3. Kesse GO, Pattanayak J. Does investing in intellectual capital improve productivity? Panel evidence from commercial banks in India. Borsa Istanbul Review. 2019.

4. Nimtrakoon S. The relationship between intellectual capital, firms' market value and financial performance: Empirical evidence from the ASEAN. Journal of Intellectual Capital. 2015;16(3):587-618.

5. Campanella F, Derhy A, Gangi F. Knowledge management and value creation in the post-crisis banking system. Journal of Knowledge Management. 2018.

6. Yi A, Davey H. Intellectual capital disclosure in Chinese (mainland) companies. Journal of Intellectual Capital. 2010;11(3):326-47.

7. Shih K-H, Chang C-J, Lin B. Assessing knowledge creation and intellectual capital in banking industry. Journal of Intellectual Capital. 2010;11(1):74-89.

8. Barathi Kamath G. The intellectual capital performance of the Indian banking sector. Journal of Intellectual capital. 2007;8(1):96-123.

9. Leonard D, Sensiper S. The role of tacit knowledge in group innovation. California Management Review. 1998;40(3):112-32.

10. Nonaka I, Toyama R, Konno N. SECI, Ba and leadership: a unified model of dynamic knowledge creation. Long Range Planning. 2000;33(1):5-34.

11. Ozkan N, Cakan S, Kayacan M. Intellectual capital and financial performance: A study of the Turkish Banking Sector. Borsa Istanbul Review. 2017;17(3):190-8.

12. Pulic A. VAIC ${ }^{\text {TM }}$-an accounting tool for IC management. International Journal of Technology Management. 2000;20(5-8):702-14.

13. Alhassan AL, Asare N. Intellectual capital and bank productivity in emerging markets: Evidence from Ghana. Management Decision. 2016;54(3):589-609.

14. Pourmozafari A, Heyrani F, Moeinadin M. The examination of relationship between intellectual capital and financial performance according to the modulating role of competitive advantage. International Journal of Academic Research in Accounting, Finance and Management Sciences. 2014;4(1):188-200.

15. Chahal H, Bakshi P. Measurement of intellectual capital in the Indian banking sector. Vikalpa. 2016;41(1):61-73.

16. Vidyarthi H. Dynamics of intellectual capitals and bank efficiency in India. The Service Industries Journal. 2018:1-24.

17. Tran DB, Vo DH. Should bankers be concerned with Intellectual capital? A study of the Thai banking sector. Journal of Intellectual Capital. 2018;19(5):897-914.

18. Poh LT, Kilicman A, Ibrahim SNI. On intellectual capital and financial performances of banks in Malaysia. Cogent Economics \& Finance. 2018;6(1):1453574. 
19. Nawaz T, Haniffa R. Determinants of financial performance of Islamic banks: An intellectual capital perspective. Journal of Islamic Accounting and Business Research. 2017;8(2):130-42.

20. Juliansyah H, Mellita Sari CP, Andriyani D, Abbas T, Sanusi I. Efficiency of conventional versus Islamic commercial banks in Indonesia 2014-2016 using data envelopment analysis. International Journal of Recent Technology and Engineering. 2019;7(6):1436-9.

21. Edvinsson L, Stenfelt C. Intellectual capital of nations - for future wealth creation. Journal of Human Resource Costing \& Accounting. 1999;4(1):21-33.

22. Meles A, Porzio C, Sampagnaro G, Verdoliva V. The impact of the intellectual capital efficiency on commercial banks performance: Evidence from the US. Journal of Multinational Financial Management. 2016;36:64-74.

23. .Meritum P. Guidelines for managing and reporting on intangibles. Fundación Airtel-Vodafone. 2002.

24. Kehelwalatenna S. Intellectual capital performance during financial crises. Measuring Business Excellence. 2016;20(3):55-78.

25. Joshi M, Cahill D, Sidhu J. Intellectual capital performance in the banking sector: An assessment of Australian owned banks. Journal of Human Resource Costing \& Accounting. 2010;14(2):151-70.

26. Mavridis DG. The intellectual capital performance of the Japanese banking sector. Journal of Intellectual capital. 2004;5(1):92-115.

27. Adesina KS. Bank technical, allocative and cost efficiencies in Africa: The influence of intellectual capital. The North American Journal of Economics and Finance. 2019.

28. Ousama AA, Fatima AH. Intellectual capital and financial performance of Islamic banks. International Journal of Learning and Intellectual Capital. 2015;12(1):1-15.

29. Tiwari R, Vidyarthi H. Intellectual capital and corporate performance: A case of Indian banks. Journal of Accounting in Emerging Economies. 2018;8(1):84105.

30. Mohammed AA, Irbo MM. Intellectual capital and firm performance nexus: Evidence from Ethiopian private commercial banks. International Journal of Learning and Intellectual Capital. 2018;15(3):189-203.

31. Attarit T. Analysis of mediating effect of intellectual capital efficiency linking board of directors' characteristics and firm performance: Empirical evidence from thai listed companies: Rajamangal University of Technology Thanyaburi. Faculty of Business Administration.; 2016

32. Hajer C, Anis J. Analysis of the impact of governance on bank performance: Case of commercial tunisian banks. Journal of the Knowledge Economy. 2016:1-25.

33. Athanasoglou PP, Brissimis SN, Delis MD. Bankspecific, industry-specific and macroeconomic determinants of bank profitability. Journal of International Financial Markets, Institutions and Money. 2008;18(2):121-36.

34. Nawaz T. Intellectual Capital, Financial Crisis and Performance of Islamic Banks: Does Shariah Governance Matter? International Journal of Business and Society. 2017;18(1):211.

35. Al-Musali MA, Ku Ismail KNI. Cross-country comparison of intellectual capital performance and its impact on financial performance of commercial banks in GCC countries. International Journal of Islamic and Middle Eastern Finance and Management. 2016;9(4):512-31.

36. Breusch TS, Pagan AR. The Lagrange multiplier test and its applications to model specification in econometrics.
The 53.

37. Hausman JA. Specification tests in econometrics Econometrica: Journal of the Econometric Society. 1978:1251-71.

38. Frondel M, Vance C. Fixed, random, or something in between? A variant of Hausman's specification test for panel data estimators. Economics Letters. 2010;107(3):327-9.

39. Mondal A, Ghosh SK. Intellectual capital and financial performance of Indian banks. Journal of Intellectual Capital. 2012;13(4):515-30.

\section{AUTHORS PROFILE}

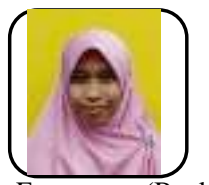

Sarah Athirah Saruchi is a third-year PhD student a Azman Hashim International Business School, Kuala Lumpur, Malaysia. She received a bachelor degree in Shariah (Islamic Economy and Banking) from Yarmouk University of Jordan and a master's degree in Islamic Economy (Banking) from Universiti Kebangsaan Malaysia. She is interested in intellectual capital, corporate governance and any subjects related to banking and Islamic economy.

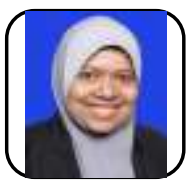

Noraiza Mohd Zamil is a senior lecturer at Azman Hashim International Business School, Kuala Lumpur Malaysia. She earned her master's degree from International Islamic University Malaysia and she received her doctorate degree from University, United Kingdom. She is interested in accounting, financeand any subjects related to banking.

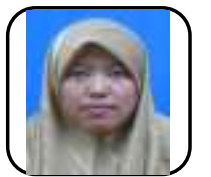

Rohaida Basiruddin is an Associate Professor and she holds a $\mathrm{PhD}$ in Accounting and Finance from Durham University Business School, UK and currently teaches accounting subject for MBA and DBA programs. She has been involved in academic research for the last ten years and supervised $\mathrm{PhD}$ students for the last seven years. Her research interests are corporate governance, audit, earnings management and Islamic banking

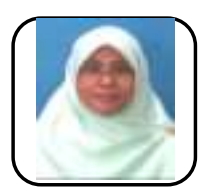

Siti Zaleha Abdul Rasid is an Associate Professo in Accounting and Finance. She is an Associate Member of Malaysian Institute of Accountant, an advocate member of Certified Institute of Management Accountant (CIMA), a research panellist of the Chartered Institute of Management Accountant (CIMA) Center of Excellence Southeast Asia and a member of British Accounting and Finance Association. She is also a member of the Harvard Business School Alumni Club of Malaysia

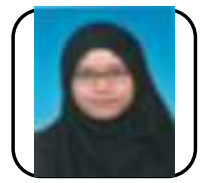

Nor Faezah Ghazi Ahmad is a third-year PhD student at Azman Hashim International Busines School, Kuala Lumpur, Malaysia. She received a bachelor degree from Universiti Sains Islam Malaysia, Negeri Sembilan, Malaysia and a master's degree in Islamic Economy (Banking) from Universit Kebangsaan Malaysia. She is interested in bank lending and any subjects related to banking. 